\title{
Are Indonesian Sign Language and Total Communication Beneficial for Teachers in Inclusive School?
}

\author{
Khofidotur Rofiah, Febrita Ardianingsih, Ima Kurrotun Ainin, Sujarwanto \\ Special Education Department \\ Universitas Negeri Surabaya \\ Surabaya, Indonesia \\ khofidoturrofiah@unesa.ac.id
}

\begin{abstract}
Deaf children experience obstacles in language development and speech because there is no sound imitation process. They need speech and language coaching in accordance with the level of hearing loss. Lack of understanding both oral and written language often causes deaf children to misinterpret something that can be a pressure for his emotions. This pressure can cause deaf children to show an attitude of self-closing, aggressive action and lack of confidence. The expected results of this activity are as follows: (1) Enriching the knowledge of special supervisor teachers about the characteristics of deaf learners, effective communication strategies for deaf learners, causes and classification of medical impairments, and total communication through the Indonesian sign language system (SIBI) for deaf learners, and (2) Enhancing skills of special counsellor teachers in communicating effectively with deaf learners and the application of total communication through the Indonesian sign language system (SIBI) for deaf students. The subjects of the training were school principals, inclusive coordinators, and special counselling teachers in 14 partner schools with 40 teachers who were trained over three days to gain knowledge and skills about the Indonesian Language Sign System (SIBI). The activities were conducted on campus and partner schools for three weeks according to the planned procedure by involving community service team members with the appropriate scientific background. The researchers, in these activities, were intended to make materials and gave comprehensive training including: (1) characteristics of deaf learners, (2) effective communication strategies for deaf learners, (3) causes and classification of medical impairments, (4) total communication through Indonesian sign language system (SIBI) for deaf students and (5) the practice of applying total communication through Indonesian sign language system (SIBI) for deaf students.
\end{abstract}

Keywords-indonesian sign language; special teacher; children with hearing impairment; inclusive education.

\section{INTRODUCTION}

The total of deaf learners in inclusive education is $25 \%$ compared to students with other types of disorders. The education for inclusive students requires different curriculum with the regular students, especially for deaf students [1]. This is very attention-grabbing considering the language characteristics and communication of deaf children which are mostly nonverbal. The use of nonverbal communication of deaf learners is caused by obstacles in hearing that give a great impact on language skills, including the ability to read and communicate to surrounding.

Total communication is a form of effective communication for students with special needs. Some definitions of total communication are formulated by experts in particular, in the field of education for people with hearing impairment. The emphasis and point of view are diverse, but the essence is the same. Some other experts view total communication as a philosophical approach, which emphasizes the existence of children. However, the essence of total communication is a philosophical approach that tries to develop children's communication in total, by utilizing whatever they have on themselves that can be used as a tool for communication. Although total communication includes various components, it does not mean that each component is total communication, sign language or finger spelling. It is because total communication is a philosophical approach, not a method or method applied in education for people with hearing impairment.

The need for enriching knowledge of total communication skills for special tutors in schools providing inclusive education is needed for deaf learners in the learning process. Therefore, education and training in total communication through the Indonesian sign language system (SIBI) for special tutors in schools providing inclusive education becomes the focus of this community service.

This is in line with the results of the analysis of the group team at the school implementing inclusive education related to the needs and problems that must be resolved immediately which is the existence of non-verbal communication that has been standardized for the teaching of students in schools, namely the Indonesian Language Sign System (SIBI) which will be trained to the tutor teacher specifically for this activity.

\section{A. Hearing Impairment}

"Hearing impairment" is used in this study as a broad term covering all degrees and types of hearing loss. A hearing impairment is a hearing loss that prevents a person from 
completely receiving sounds through the ear [2], [3]. Hearing loss is often classified by means of different categories: mild (20-44dB), moderate $(45-69 \mathrm{~dB})$, severe $(70-90 \mathrm{~dB})$ and profound (90dB above) hearing loss. A loss in the profound range is often referred to as deafness. Individuals with hearing impairment may be described as deaf or hard of hearing.

1) "Deaf is defined as a hearing disorder that limits an individual's aural/oral communication performance to the extent that the primary sensory input for communication may be other than the auditory channel" [4].

2) "Hard of hearing is defined as a hearing disorder, whether fluctuating or permanent, which adversely affects an individual's ability to communicate. The hard-of-hearing individual relies on the auditory channel as the primary sensory input for communication "[4].

Hearing function is a very fundamental mean for the process of understanding language since human beings are born. In the next stage, the ability to hear is the foundation for both formal and non-formal education.

\section{B. Language Development}

Language development in deaf children further requires special guidance. According to Ling, Northcot and Pollack with early intervention in language skills, the development of the language of children with hearing impairment will be very close to language development of normal children [5]

In terms of language, deaf children generally have the following characteristics: (1) poor in vocabulary, (2) difficulty in comprehending long and related sentences, (3) difficulty in understanding phrases containing figurative meanings or words, abstract words and (4) difficulty in mastering the rhythm and style of language.

The limitations of deaf children in hearing and obstructing the development of the child's language lead to limited information received, that this can hamper the abstraction so that it can inhibit them to reach more knowledge.

According to [6], the average intelligence of a child with hearing impairment is lower than that of a normal hearing child. This can be seen from the results of mental tests in children with hearing impairment showing the results are lower than the normal child. However, on non-verbal tests, deaf children are almost similar to normal children.

The results of study by Mac Kane, Feterson found out that the intelligence of hearing-impaired children is lower than that of normal hearing children[7]. While the results of research conducted by Bishop, Kirk and Streng, Buchard and Myklebust showed that intelligence in children with hearing impairment is not different from normal child hearing.

According to Pinter, a psychologist working at the institution of deaf children suggests that children are deaf in motor and mechanical terms and in concrete intelligence are the same as normal children, but in terms of verbal intelligence and in terms of academic ability, it indicates a limitation compared with children who are able to hear[3].
Guidance of language skills in children with hearing impairment needs to be given on the basis that the problems they face are very complex. Hence, in order to develop the ability of children with hearing impairment and to develop optimally in accordance with the ability and disability, the first step should be given in education is the guidance of language skills[5]. Early intervention in the guidance of language skills will help children with hearing impairment in their development, so it does not differ greatly from normal hearing.

In the guidance of language skills in children with hearing impairment, it includes (1) listening skills, (2) speaking skills, (3) reading skills, and (4) writing skills. In giving guidance, language skills are delivered using communicative approach. According to [8], the approach is called communicative language approach.

\section{Sign Language}

Sign language is the primary means of communication for ones who are difficult to hear and speak around the world. Sign language puts emphasis on visual possibilities as the participants are unable to hear sound patterns.

Sign language uses different signs, body postures and gestures as opposed to sound patterns for communication and evolved like any other spoken language. Sign language communication involves not only hand gestures (manual signs) but also non-manual signs conveyed through facial expressions, head movements and body postures.

For example, in order to understand a signed sentence as shown in Fig 1.1: 'Are You Studying?', the signals in both manual and non- manual channels (facial expression) need to be recognized and expressions of head movements and body postures need to be fused. Moreover, in order to understand a signed sentence as shown in Fig 1.1: 'Are You Studying?', the signals in both, the manual and non -manual channels (facial expression) need to be recognized and fused.

Around 177 sign language systems are available globally. Few of them are American Sign Language (ASL), British Sign Language (BSL), Chinese Sign Language (CSL), Australian Sign Language (Auslan) and so on. Sign language evolves naturally like any other spoken language and always does not have a strong connection with the native language. For example, British Sign Language (BSL) and American Sign Language (ASL) differ significantly although both countries are English speaking countries. As an example, ASL mainly uses single handed while BSL uses both hands. In addition, ASL has a strong connection with French sign language and Arabic sign language.

However, ASL varies significantly with BSL and Australian sign language. Each sign language has its own independent standardization within that country. Sign languages are well structured languages with phonology, morphology, syntax and grammar. Initial breakthrough in sign language research was in ASL which has remained as one of the most investigated sign languages in terms of linguistic structure. However, total adoption of methods of one sign language system to another system would not be always possible due to the inherent complexities of each. The main 
problem is that sign languages differ from country to country and region to region and signs and gestures are not uniform across different language systems. Sign Languages are:

- NOT same all over the world

- NOT just 'languages of hands' stands alone. It also contains non-manual gestures.

- $\quad$ NOT just gestures, but also do have their own grammar.

\section{METHOD}

This activity was carried out using the following methods.

\section{A. Pre-test and Post-test}

This test was conducted to determine the knowledge of special tutor teachers about the characteristics of deaf learners, effective communication strategies for deaf students, causes and classification of medical impairment, and total communication through the Indonesian sign language system (SIBI) for deaf learners. The results of the pretest were used as a reference for the activity and comparison material. The results of the post-test were compared with the results of the pre-test to see the improvement of teachers' knowledge of the characteristics of deaf students, effective communication strategies for deaf students, causes and classification of medical impairment, and total communication through the Indonesian sign language system for deaf students.

\section{B. Lecture and question and answer}

Lectures and question and answer were chosen as a method to share the knowledge about the characteristics of deaf students, effective communication strategies for deaf students, causes and classification of medical impairment, and total communication through the Indonesian sign language system (SIBI) for deaf students. This method was done to enrich the teachers' knowledge about it.

\section{Trining and Practice}

This method was carried out to improve teachers' skills in communicating effectively with deaf students and the application of total communication through the Indonesian sign language system (SIBI) for deaf students. Teachers were equipped with skills first and then were given the opportunity to practice their skills towards their students.

\section{Monitoring}

This method was monitoring the implementation of total communication through the Indonesian sign language system (SIBI) for deaf learners which has been done before. This method was carried out if in practice the irregularities in the implementation of total communication through the Indonesian sign language system (SIBI) for deaf students by teachers to their students were found, according to the procedure, it was necessary to re-monitor.

\section{RESULT AND DISCUSSION}

This activity was carried out through several stages of the process. It started from planning and concepts about this activity then continued with the formation of a small team implementing activities consisting of the main research team and assisted students. Then, the two-day training activities were carried out to enrich the knowledge of special tutors about the characteristics of deaf students, effective communication strategies for deaf learners, causes and classification of medical impairment, and total communication through the Indonesian sign language system (SIBI) for deaf students. Furthermore, it was intended to improve the skills of special counsellor teachers in communicating effectively with deaf learners and the application of total communication through the Indonesian sign language system (SIBI) for deaf students. In addition, there is also an increase in non-verbal communication between teachers and deaf students in this case through the Indonesian sign language system (SIBI). The following is a breakdown of the activities in this training.

\begin{tabular}{|l|l|}
\hline No & \multicolumn{1}{|c|}{ Material } \\
\hline 1 & Pre-test \\
\hline 2 & $\begin{array}{l}\text { Characteristics of deaf learners, effective communication strategies } \\
\text { for deaf students, total communication through the Indonesian sign } \\
\text { language system (SIBI) for deaf students }\end{array}$ \\
\hline 3 & Causes and classification of deafness in medical \\
\hline 4 & $\begin{array}{l}\text { Total communication through the Indonesian sign language system } \\
\text { (SIBI) for deaf students }\end{array}$ \\
\hline 5 & $\begin{array}{l}\text { Practice of total communication through the Indonesian sign } \\
\text { language system (SIBI) for deaf students }\end{array}$ \\
\hline 6 & $\begin{array}{l}\text { Characteristics of deaf students, effective communication strategies } \\
\text { for deaf students }\end{array}$ \\
\hline 7 & Causes and classification of medical impairment \\
\hline 8 & $\begin{array}{l}\text { Total communication through the Indonesian sign language system } \\
\text { (SIBI) for deaf students }\end{array}$ \\
\hline 9 & $\begin{array}{l}\text { Total communication through the Indonesian sign language system } \\
\text { (SIBI) for deaf students }\end{array}$ \\
\hline 10 & Post-test \\
\hline 11 & $\begin{array}{l}\text { Monitoring Implementation of total communication through the } \\
\text { Indonesian sign language system (SIBI) for deaf learners }\end{array}$ \\
\hline
\end{tabular}

From the training activities held, there are several assumptions of the researcher as followed:

- There is an increase in post test scores compared to pretest scores related to teachers' knowledge of the characteristics of deaf learners, effective communication strategies for deaf students, causes and classification of medical impairment, and total communication through the system Indonesian sign language (SIBI) for deaf students. The following can be illustrated through the following graph.

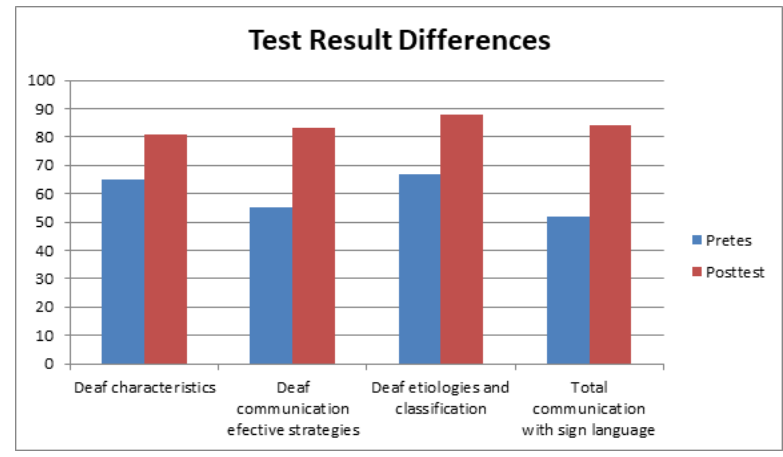

Graph 1. The Pre-Posttest Result 
- There is an application of special guidance for teachers' skills in communicating effectively with deaf students and the application of total communication through the Indonesian sign language system (SIBI) for deaf students in their respective schools.

- There is a positive response from the school environment, especially deaf students related to an increase in non-verbal communication between teachers and deaf learners through the Indonesian sign language system.

\section{REFERENCES}

[1] Pedoman Umum Penyelenggaraan Pendidikan Inklusif Direktorat PPKLK. Jakarta: Pendidikan Dasar Kementrian Pendidikan dan Kebudayaan, 2011
[2] Republik Indonesia, Departemen Pendidikan Nasional, Sistem Isyarat Bahasa Indonesia. Jakarta: Departemen Pendidikan Nasional, 2001.

[3] A. S. Sadiman, Media Pendidikan: Pengertian, Pengembangan, dan Pemanfaatannya. Jakarta: Rajawali Presss, 2012.

[4] Sardjono, Orthopaedagigik Tuna Rungu I. Surakarta: UNS Pres, 2000.

[5] S. Soewito, and S. Soejono, Komunikasi Total. Jakarta: Bumi Aksara, 2005.

[6] V. Uden, World of Language for Deaf Children: Basic Principles A Maternal Reflective Method, Amsterdam: Swetz \& Zetlinger, 1977.

[7] S. F. Moores, Educating the Deaf, Psychology Principles, and Practices, Boston: Hooughton Mifflin Company, 2000.

[8] Permanarian and T. Hernawati, Ortopedagogik Anak Tunarungu, Jakarta: Depdikbud, 1995. 